\title{
SEM Morphological Study of the Paratype of the Spinicaudatan Feiyunella zhedongensis (Chen and Shen, 1977) from Cretaceous of Linhai, Zhejiang, South-East China
}

\author{
Xiao Teng1,2, Gang $\mathrm{Li}^{3}$ \\ ${ }^{1}$ CAS Key Laboratory of Economic Stratigraphy and Palaeogeography, Nanjing Institute of Geology and Palaeontology and Center \\ for Excellence in Life and Paleoenvironment, Chinese Academy of Sciences, Nanjing, China \\ ${ }^{2}$ University of Science and Technology of China, Hefei, China \\ ${ }^{3}$ State Key Laboratory of Palaeobiology and Stratigraphy, Nanjing Institute of Geology and Palaeontology and Center for \\ Excellence in Life and Paleoenvironment, Chinese Academy of Sciences, Nanjing, China \\ Email: *gan gli@nigpas.ac.c
}

How to cite this paper: Teng, X. and Li, G. (2019) SEM Morphological Study of the Paratype of the Spinicaudatan Feiyunella zhedongensis (Chen and Shen, 1977) from Cretaceous of Linhai, Zhejiang, South-East China. Open Journal of Geology, 9, 613-615.

https://doi.org/10.4236/ojg.2019.910055

Received: August 16, 2019

Accepted: September 20, 2019

Published: September 23, 2019

Copyright (๑) 2019 by author(s) and Scientific Research Publishing Inc. This work is licensed under the Creative Commons Attribution International License (CC BY 4.0).

http://creativecommons.org/licenses/by/4.0/

\begin{abstract}
Spinicaudatans, a suborder of the abandoned taxonomic group "Conchostraca", are very useful for biostratigraphic subdivision and correlation of the non-marine successions, remarkably in otherwise fossil-scarce red beds. Feiyunella, a monospecies spinicaudatan genus, was established based on specimens from sediments of Upper Cretaceous red beds in different localities of Zhejiang Province. The morphological examination under a scanning electron microscope of the type specimens of Feiyunella zhedongensis (Chen and Shen, 1977) has found that the paratype from the Fangyan Formation at Xiaoling of Linhai City, Zhejiang Province, is not Feiyunella, but a younger individual of Linhaiella.
\end{abstract}

\section{Keywords}

Spinicaudatan, Feiyunella, Linhaiella, Taxonomy, Cretaceous, South-East China

\section{Introduction}

Debate continues about the stratigraphic correlation of the widely distributed non-marine red beds in south-east China. The spinicaudatans are one of the important groups for biostratigraphic correlation of the fossil-poor red beds [1] [2]. The Linhaiella fauna was established from the Cretaceous strata which pertain to the Fangyan Formation at the Xiaoling Section in Linhai, Zhejiang 
Province [3]. The fauna was subsequently discovered in Anxi of Fujian, Gaohe of Guangdong, China, and Kiwado of Yamaguchi, Japan. The diversity of this fauna is extremely low, only several species in two genera, Linhaiella and Feiyunella are contained [4]. A recent morphological restudy of the type specimens of Feiyunella has revealed that the Feiyunella paratype from the Xiaoling Section is Linhaiella, totally different from the holotype which was collected from the Cretaceous strata at the Konglong Section in the Zhengwan village, Wencheng, Zhejiang Province.

\section{Material and Method}

The examined specimen is a paratype (NIGPCAS 42283) of Feiyunella zhedongensis [5], which is deposited in the collection of the Nanjing Institute of Geology and Palaeontology, Chinese Academy of Sciences (NIGPCAS). The current study examined the specimens by a HITACHI SU3500 scanning electron microscope (SEM).

\section{Results and Conclusion}

The examination indicates that the paratype of Feiyunella zhedongensis (NIGPCAS 42283) is a younger individual of Linhaiella longiformis [6]: most of its growth bands are ornamented by relatively widely spaced and slender radial lirae, lirae branch to form reticulations, on external mould appearing as lender, branched grooves with intercalated fine nodules (Figure 1(b), Figure 1(c)); mesh walls are thin, mesh cell diameter ca. 5 - $10 \mu \mathrm{m}$; radial lirae on the distal
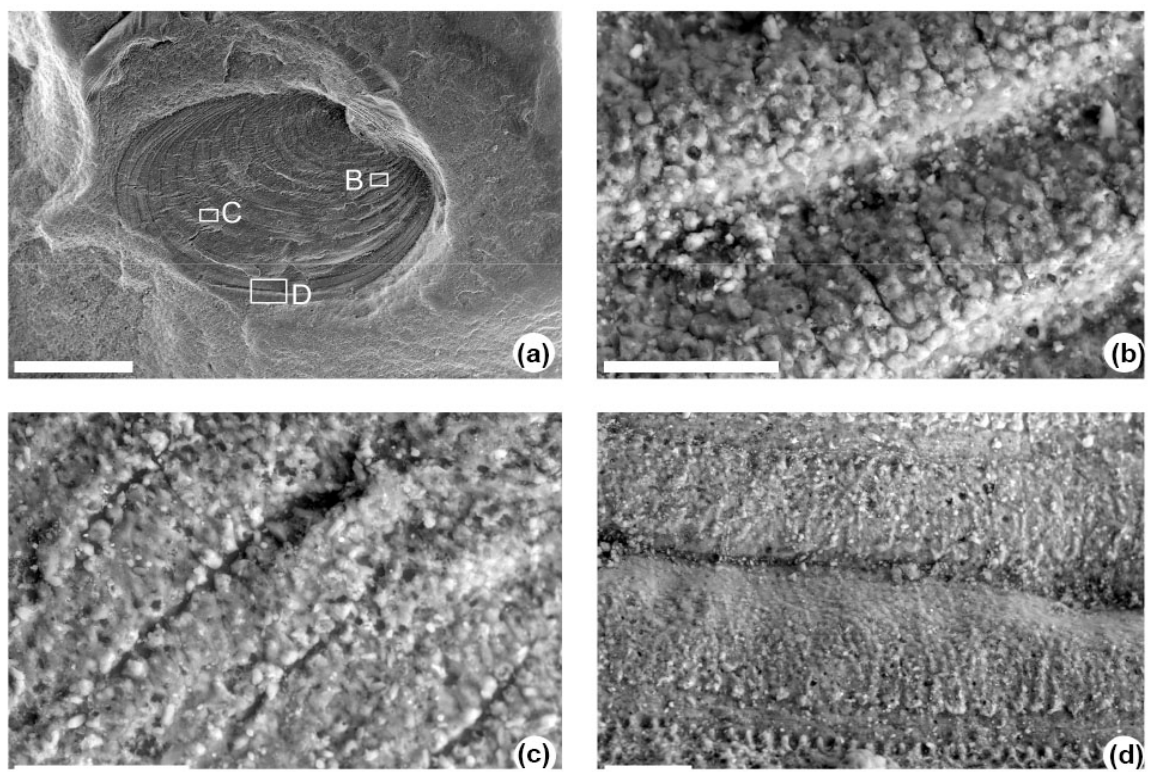

Figure 1. Linhaiella longiformis Chen and Shen, 1982, the paratype of 'Feiyunella' (NIGPCAS 42283) from the Fangyan Formation at the Xiaoling Section of Linhai, eastern Zhejiang Province. (a) External mould of a left valve; (b) (c) External mould of branched slender radial lirae on growth bands, appearing as lender, branched grooves with intercalated fine nodules; (d) External mould of ornamentation on the marginal area of the carapace. Scale bar $=1 \mathrm{~mm}$ in $\mathrm{A}, 50 \mu \mathrm{m}$ in (b)-(d). 
most three growth bands are almost disappeared, especially on the upper part of each growth band; meshes change to evenly distributed puncta; and near the margin of each growth band, 2 - 3 rows of puncta are relatively deeper than others on the same growth band; on external mould, puncta appear as linearly arranged nodules on the lower part of each growth bands (Figure 1(d)). In contrast, growth bands in the lower part of the true Feiyunella carapace are ornamented by long and straight lirae, the lirae is stouter than that in Linhaiella. It was usually reported that Feiyunella co-occurred with Linhaiella; however, type specimens of the referred species are poorly preserved to identify. A further study with more focus on more taxonomic features of the true Feiyunella is therefore suggested; it would be helpful for biostratigraphic correlation of the Cretaceous non-marine red beds in south-east China.

\section{Acknowledgements}

The study is supported by the Strategic Priority Research Program of the Chinese Academy of Sciences (XDB26000000) and the National Natural Science Foundation of China $(41572006,41688103,41972007)$. This is a contribution to UNESCO-IUGS IGCP Project 679.

\section{Conflicts of Interest}

The authors declare no conflicts of interest regarding the publication of this paper.

\section{References}

[1] Li, G., Hirano, H., Batten, D.J., Wan, X.Q., Willems, H. and Zhang, X.Q. (2010) Biostratigraphic Significance of Spinicaudatans from the Upper Cretaceous Nanxiong Group in Guangdong, South China. Cretaceous Research, 31, 387-395. https://doi.org/10.1016/j.cretres.2010.05.003

[2] Li, G., Chen, P.J., Wang, D.Y. and Batten, D.J. (2009) The Spinicaudatan Tylestheria and Biostratigraphic Significance for the Age of Dinosaur Eggs in the Upper Cretaceous Majiacun Formation, Xixia Basin, Henan Province, China. Cretaceous Research, 30, 477-482. https://doi.org/10.1016/j.cretres.2008.09.002

[3] Chen, P.J. and Shen, Y.B. (1982) Late Mesozoic Conchostracans from Zhejiang, Anhui and Jiangsu Provinces. Palaeontologica Sinica, New Series B, 17, 1-117. (In Chinese)

[4] Chen, P.J., Li, G. and Batten, D.J. (2007) Evolution, Migration and Radiation of Late Mesozoic Conchostracans in East Asia. Geological Journal, 42, 391-413. https://doi.org/10.1002/gj.1064

[5] Chen, P.J. and Shen, Y.B. (1977) On the Discovery of Afrograptidae (Conchostraca) in Zhejiang with Its Significance. Acta Palaeontologica Sinica, 16, 81-94.

[6] Teng, X. and Li, G. (2018) Morphological Study of Linhaiella (Spinicaudata) from the Upper Cretaceous in Zhejiang, South-East China. Cretaceous Research, 92, 184-194. 